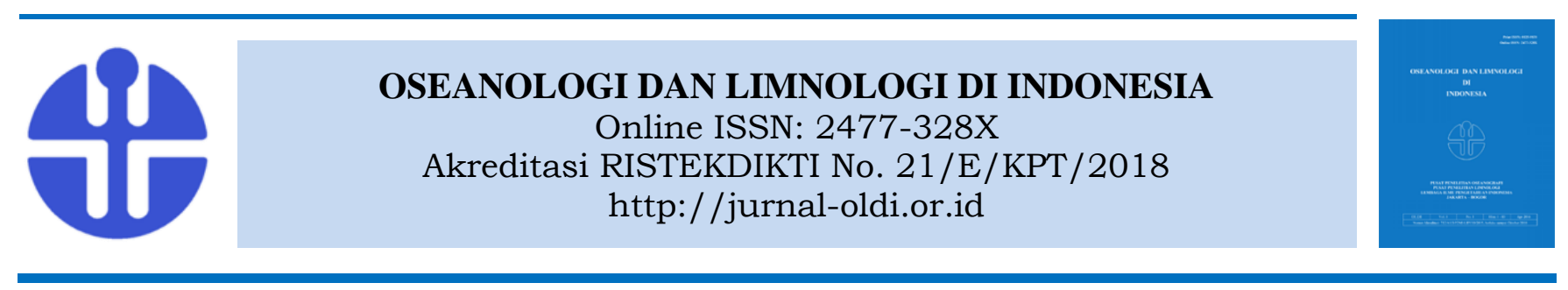

\title{
Deteksi Tinggi Vegetasi di Delta Mahakam dengan Penginderaan Jauh
}

\author{
Nanin Anggraini ${ }^{1}$ dan Atriyon Julzarika ${ }^{2}$ \\ ${ }^{1}$ Pusat Pemanfaatan Penginderaan Jauh, LAPAN, Jl. Kalisari No 8, Jakarta \\ ${ }^{2}$ Teknik Geodesi Geomatika UGM, Jl. Grafika No 2, Yogyakarta
}

E-mail: nanin_rain@yahoo.com dan verbhakov@yahoo.com

Submitted 9 Agustus 2018. Reviewed 20 August 2019. Accepted 19 November 2019.

DOI: 10.14203/oldi.2019.v4i3.212

\begin{abstract}
Abstrak
Tinggi pohon (vegetasi) adalah jarak tegak antara puncak pohon terhadap permukaan tanah. Tinggi vegetasi menjadi salah satu parameter bagi pertumbuhan vegetasi. Ada berbagai metode untuk mengukur tinggi vegetasi, salah satunya dengan menggunakan teknologi penginderaan jauh. Penelitian ini bertujuan untuk pemetaan tinggi vegetasi di Delta Mahakam dengan model tinggi dari penginderaan jauh. Model tinggi yang digunakan adalah Model Permukaan Digital (MPD) dan Model Terrain Digital (MTD). MPD dibuat dari gabungan hasil interferometri citra satelit ALOS PALSAR dengan citra X SAR, Shuttle Radar Topography Mission (SRTM), dan tinggi geodetik dari satelit Icesat/GLAS. Penggabungan ini menggunakan metode integrasi Model Elevasi Digital (MED). Bidang geoid yang digunakan adalah EGM 2008. Langkah selanjutnya adalah koreksi terhadap kesalahan tinggi pada MPD. Koreksi terrain dilakukan untuk mengubah MPD menjadi MTD. Tinggi vegetasi diperoleh dari pengurangan MPD menjadi MTD. Uji akurasi vertikal mengacu ke toleransi 1,96\% (95\%) sebesar minimal $80 \mathrm{~cm}$. Pada MPD, diperoleh nilai akurasi vertikal sebesar 60,4 cm sehingga MPD ini bisa digunakan pada pemetaan 1:10.000. Sedangkan pada MTD diperoleh nilai uji akurasi vertikal sebesar $37 \mathrm{~cm}$ sehingga dapat juga digunakan untuk pemetaan skala 1:10.000. Berdasarkan hasil perhitungan MPD dan MTD, tinggi vegetasi di Delta Mahakam bervariasi antara 0 - $64 \mathrm{~m}$.
\end{abstract}

Kata Kunci: tinggi vegetasi, MPD, MTD, Delta Mahakam

\section{Abstract}

Detection of Vegetation Height in Mahakam Delta Using Remote Sensing. The vegetation height is a vertical distance between top of the vegetation to ground surface. Vegetation height is one of the parameters for vegetation growth. There are various methods to measure vegetation height; one of them is the use of remote sensing technology. This study aims to map vegetation height in Mahakam Delta by using height models derived from remote sensing data. Such models are Digital Surface Model (DSM) and Digital Terrain Model (DTM). DSM was generated using a combination of interferometric processing ofALOS PALSAR interferometry, XSAR, Shuttle Radar Topography Mission (SRTM), and geodetic height of Icesat / GLAS satellite imagery. This integration technique incorporated the Digital Elevation Model (DEM) method. The geoid model used in this study was EGM 2008. The following step was the correction of height errors of DSM. Terrain correction was undertaken to convert DSM into DTM, while vegetation 
heights were obtained from subtraction of DSM and DTM. Vertical accuracy verification refers to a tolerance of $1.96 \sigma(95 \%)$ or $\sim 80 \mathrm{~cm}$. In DSM, a vertical accuracy value of $60.4 \mathrm{~cm}$ was obtained so that the DSM is feasible for mapping with scale of 1: 10,000, while the DTM was $37 \mathrm{~cm}$ so it is also applicable for mapping with such scale. Based on the subtraction of DSM and DTM, the vegetation heights in Mahakam Delta varied between 0 and $64 \mathrm{~m}$.

Keywords: vegetation height, DSM, DTM , Mahakam Delta

\section{Pendahuluan}

Perairan darat adalah semua bentuk genangan air di permukaan bumi ke arah darat mulai dari garis pasang surut terendah sampai kepada danau vulkanik yang berada di pegunungan, baik berair payau atau tawar seperti sungai, rawa, danau, situ, lahan basah, reservoir, genangan, embung, dan bendungan (LIPI, 2018). Salah satu contoh perairan daratan adalah Delta Mahakam.

Delta Mahakam yang terletak di Kabupaten Kutai Kartanegara Propinsi Kalimantan Timur adalah suatu kawasan yang terbentuk akibat adanya endapan dari muara Sungai Mahakam dengan Selat Makasar (Arifantia et al., 2019, Gastaldo, 2010). Sayekti (2002) menyatakan bahwa lebar dari Delta Mahakam mencapai $80 \mathrm{~km}$ dan luas $1500 \mathrm{~km}^{2}$. Secara geografis terletak pada $0^{\circ} 21^{\prime}-1^{\circ} 10^{\prime} \mathrm{LS}$ dan $117^{\circ} 15^{\prime}-117^{\circ} 40^{\prime}$ BT dan secara administratif, Delta Mahakam terletak di Kecamatan Anggana, Muara Jawa, dan Sangasanga.

Dataran Delta Mahakam terbagi menjadi empat zona vegetasi, yaitu hutan tanaman keras tropis daratan rendah, hutan campuran tanaman keras dan palma dataran rendah, hutan rawa nipah dan hutan bakau. Sebanyak $60 \%$ dari luas dataran Delta Mahakam berada pada zona rawa nipah dan bakau yang selanjutnya disebut sebagai hutan mangrove (Yayasan Mangrove Lestari, 2012).

Hutan mangrove di Delta Mahakam mengalami kerusakan yang sangat akut, diperkirakan kerusakan mencapai 85 persen atau 91,906 hektar dari total luas 108,125 hektar di Kecamatan Samboja, Kabupaten Kutai Kartanegara (Kukar) (Iskandar, 2010). Kerusakan ini hanya berdasarkan informasi dua dimensi seperti penutup lahan sedangkan terdapat cara lain yang bisa digunakan untuk mengidentifikasi perubahan secara vertikal (3 dimensi), yaitu tinggi vegetasi, diameter kanopi vegetasi (Suhardimana et al., 2016), dan geovisualisasi kawasan.

Penelitian dari Noggle dan Fritz (1983) menyatakan bahwa pertumbuhan vegetasi dapat 176 dilihat dari meningkatnya tinggi vegetasi, panjang, lebar, luas daun, berat kering dari organ (akar, batang, daun dan buah), jumlah sel, dan kandungan unsur kimia tertentu. Salah satu metode yang dapat digunakan untuk deteksi tinggi vegetasi adalah dari data citra satelit dengan pendekatan model tinggi.

Model tinggi dapat dibuat dari data optik, radar, dan sonar. Model tinggi data optik tersebut menggunakan data citra satelit optik, foto udara, video (Kumay, 2015). Pada data optik, pembuatan model tinggi menggunakan metode model stereo, videogrammetri, dan depth cue perceptive. Selain data optik, data satelit radar juga dapat digunakan untuk membuat model tinggi. Data radar yang telah banyak dimanfaatkan adalah Advanced Land Observation Satellite Phased Array type L-band Synthetic Aperture Radar (ALOS PALSAR). ALOS PALSAR merupakan sensor microwave (gelombang pendek) L-band untuk observasi daratan tanpa awan dan perekaman dilakukan siang dan malam. Pembuatan model tinggi pada data radar menggunakan metode model stereo, interferometri, dan depth cue perceptive. Model tinggi yang dibuat dengan sonar dapat menggunakan data Interferometry Synhetic Aperture Sonar (IFSAS) (Julzarika, 2013).

Saat ini masalah yang dihadapi dalam penentuan tinggi relatif vegetasi adalah pemetaan secara cepat dan wilayah yang luas. Selain itu, Model Permukaan Digital (MPD) yang tersedia masih belum dilakukan koreksi kesalahan tinggi dan belum diturunkan menjadi Model Terrain Digital (MTD) (Vanicek \& Krakiwsky, 1986). Salah satu cara yang dapat digunakan untuk koreksi kesalahan tinggi dan MTD adalah dengan pendekatan secara hitung perataan (Gillani \& Wolf, 2006). Algoritma dibangun berdasarkan korelasi tinggi permukaan dengan tinggi orthometrik secara perataan kudrat terkecil. Algoritma ini yang digunakan untuk penentuan tinggi relatif permukaan, bisa untuk menghitung tinggi vegetasi. Vegetasi ini dideteksi dengan klasifikasi. Kelas yang digunakan dalam penelitian ini adalah vegetasi dan nonvegetasi. Tujuan dari penelitian ini adalah melakukan 
deteksi tinggi vegetasi di delta sungai Mahakam dengan penginderaan jauh menggunakan MPD dan MTD.

\section{Metodologi}

\section{Data dan Lokasi}

Data yang digunakan pada penelitian adalah ALOS PALSAR dua polarisasi yaitu $\mathrm{HH}$ dan HV dengan level data 1.0 atau raw data. Data tersebut diakuisisi pada tahun 2008-2010 dengan lokasi penelitian di sekitar Delta Mahakam Kalimantan Timur (Gambar 1). Selain ALOS PALSAR, data X Synthetic Aparture Radar (X SAR), Shuttle Radar Topography Mission (SRTM), dan Ice, Cloud and land Elevation Satellite/Geoscience Laser Altimeter System (ICESat/GLAS) juga digunakan pada penelitian ini. X SAR adalah data radar $\mathrm{X}$ band dengan resolusi spasial 1 busur detik (arc second) yang dimiliki oleh Jerman dan Italia. SRTM adalah data

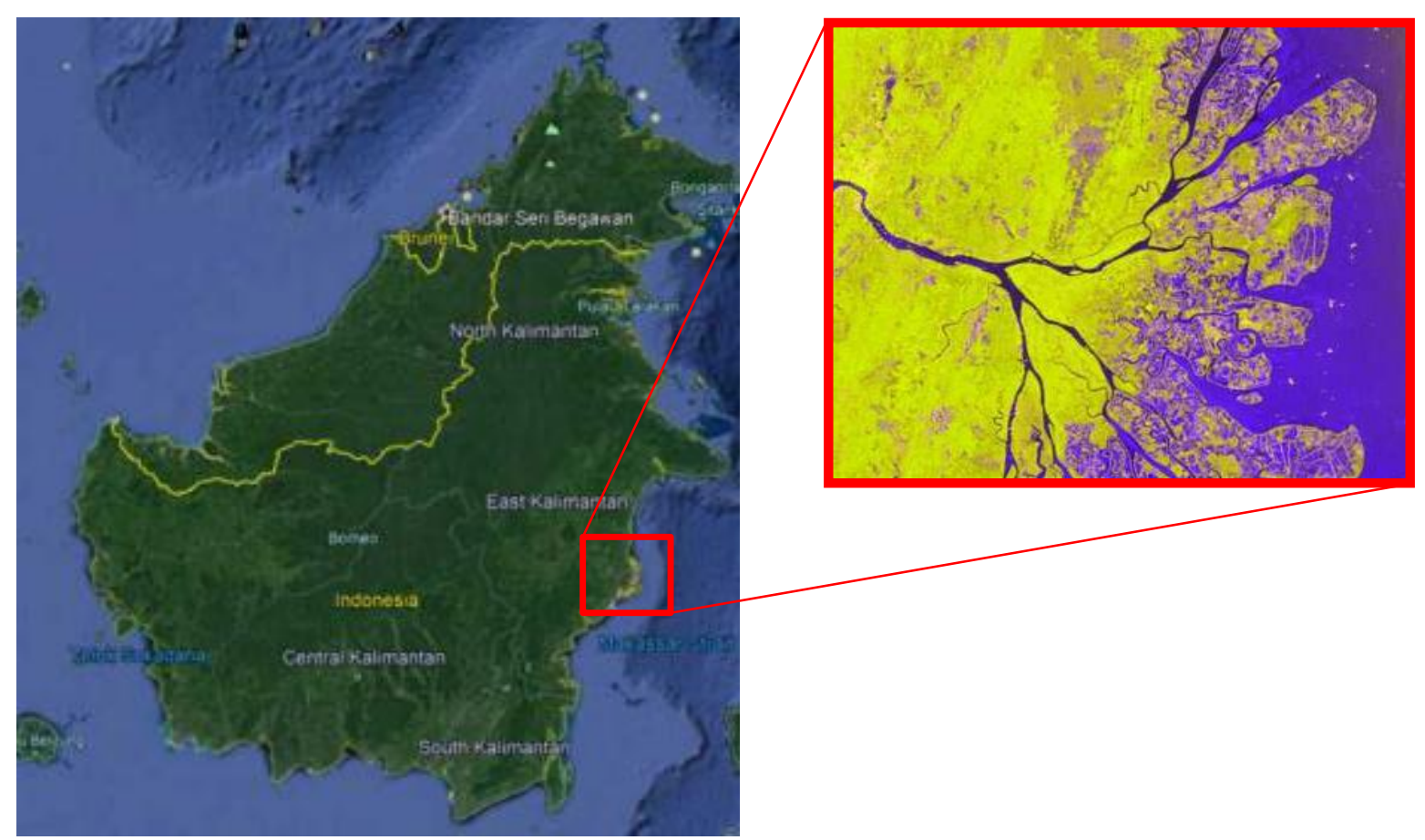

Gambar 1. Delta Mahakam, Kalimantan Timur.

Figure 1. Mahakam Delta, East Kalimantan. radar $\mathrm{C}$ band dengan resolusi spasial 3 arc second yang dimiliki oleh Amerika Serikat. Icesat/GLAS adalah satelit milik Amerika Serikat yang memiliki sensor LIDAR. Satelit ini dapat memetakan tinggi geodetik topografi.

\section{Metode}

Metode yang digunakan pada penelitian adalah konversi MPD ke MTD dengan hitung perataan kuadrat terkecil. Diagram alir penelitian ini dapat dilihat pada Gambar 2.

\section{MED}

MED adalah model elevasi bare earth atau autokorelasi permukaan tanpa ada vegetasi, bangunan, dan obyek lainnya (Petrie \& Kennie, 1987); (Li et al., 2005); (Trisakti \& Julzarika, 2011). 


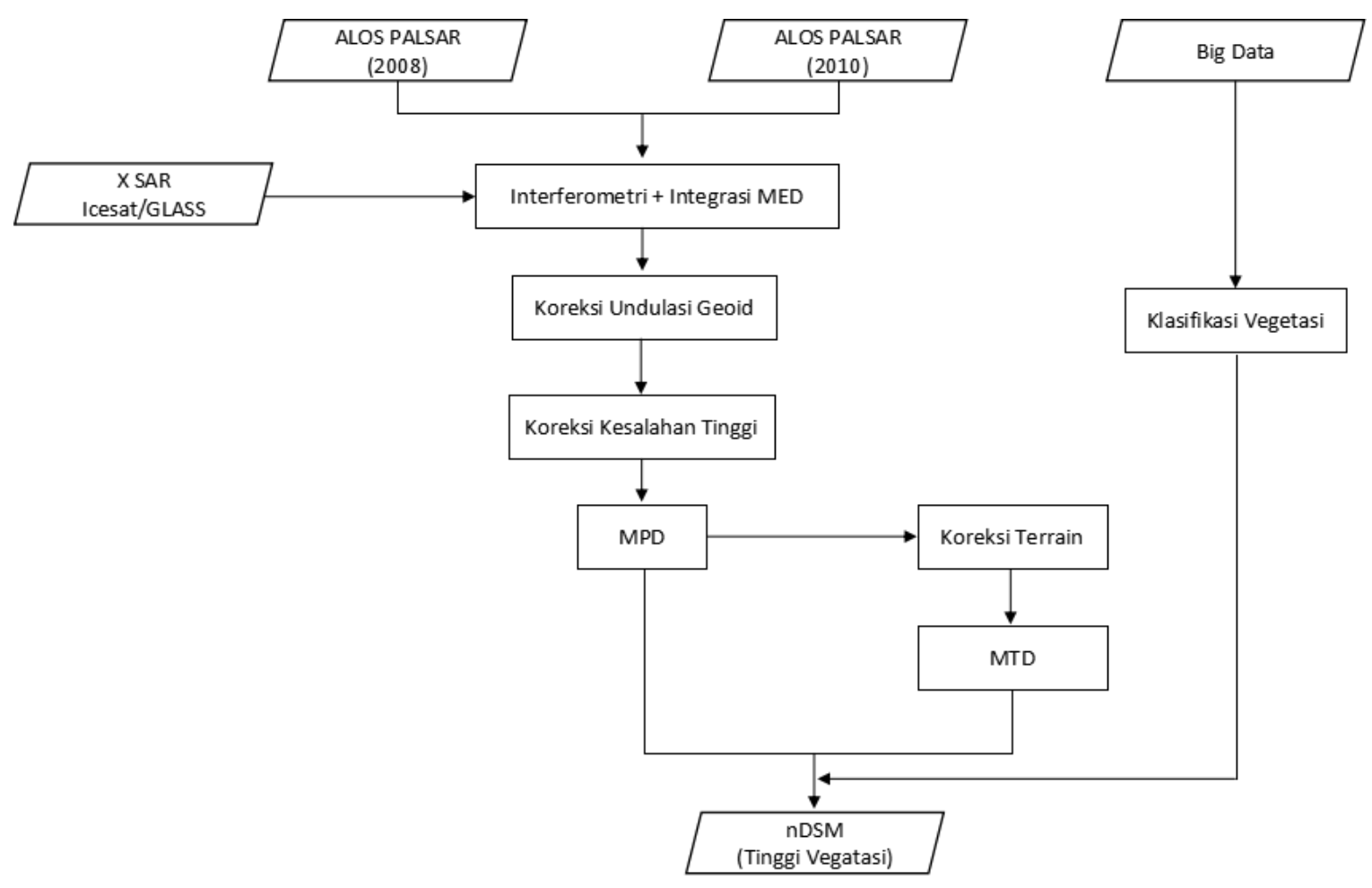

Gambar 2. Diagram alir penelitian.

Figure 2. Research flow chart.

MED diperoleh secara interferometri dari data ALOS PALSAR (Sarmap, 2017). Inteferometri merupakan salah satu metode untuk pembuatan model tinggi dengan data SAR (Goel, 2013). Data MED hasil interferometri akan diintegrasikan dengan X SAR dan Icesat/GLAS. Integrasi ini menggunakan kelebihan pada data interferometri MED, kelemahannya diganti dan diintegrasi dengan kelebihan dari data X SAR dan Icesat/GLAS (Hoja \& d'Angelo, 2010); (Hoja et al., 2006). Hal ini bertujuan untuk meningkatkan akurasi vertikal MED (Julzarika, 2015), kemudian hasil integrasi MED ini dilakukan koreksi undulasi geoid dan koreksi kesalahan tinggi. Undulasi geoid adalah selisih antara model geoid dengan bidang normal geoid. Geoid adalah bidang equipotensial yang berimpit dengan permukaan laut rerata.

Koreksi undulasi geoid bertujuan untuk membawa MED ke bidang referensi geoid tertentu yang berimpit dengan permukaan laut rerata. Penelitian ini menggunakan bidang geoid Earth Gravitational Model (EGM) 2008. Koreksi kesalahan tinggi bertujuan untuk meminimalkan kesalahan vertikal pada MED dengan memperhitungkan delapan piksel tetangganya.

\section{Koreksi Kesalahan Tinggi}

Kesalahan tinggi dibuat dari nilai standar deviasi atau kesalahan vertikal pada data model tinggi tersebut (Zimmerman \& Cressie, 1992). Kesalahan tinggi dapat dibuat dari data itu sendiri. Fill Sink adalah metode penghilangan anomali tinggi terhadap daerah cekungan sedangkan $\mathrm{Cut}$ Terrain adalah metode penghilangan anomali tinggi terhadap daerah cembung/terjal (Julzarika, 2015).

Koreksi kesalahan tinggi dilakukan dengan tiga metode yang ada, yaitu Fill Sink, Cut terrain, dan Height Error Maps. Metode Height Error Maps menghasilkan data keluaran dengan akurasi dan presisi lebih baik dari Fill Sink dan Cut Terrain. Metode Fill Sink memiliki kelebihan pada pengisian anomali nilai tinggi pada wilayah lembah, tetapi tidak bisa mengkoreksi data wilayah gunung terjal, sedangkan metode $\mathrm{Cut}$ Terrain berlaku kebalikan dan metode Fill Sink (Julzarika, 2015).

\section{MPD dan MTD}

MPD diperoleh dari koreksi kesalahan tinggi. Hasil dari MPD masih perlu dikoreksi, yaitu dengan koreksi terrain. Koreksi terrain dapat dilakukan dengan berbagai metode, seperti differential height model, differential multipolarization, DSM2DEM, tree height, manual differencing (Freeden et al., 2010). Koreksi terrain pada penelitian ini menggunakan 
metode differential height model dengan DSM2DEM. Adapun rumus DSM2DEM yang digunakan adalah sebagai berikut (Julzarika, 2011c):

$\mathrm{Z}_{\mathrm{MPD}}(d \mathrm{x}, d \mathrm{y})=\mathrm{a}_{0}+\mathrm{a}_{1} d \mathrm{x}+\mathrm{a}_{2} d \mathrm{y}+\mathrm{a}_{3} d x d y+\mathrm{hm}_{\mathrm{G}}+\varepsilon$ (1)

\section{keterangan: \\ $\mathrm{Z}_{\mathrm{MPD}} \quad$ : elevasi MPD \\ dx, dy : lokasi relatif terhadap target piksel \\ $\mathrm{a}_{0} \ldots \mathrm{a}_{3} \quad: \quad$ tinggi terrain lokal dan parameter kemiringan lahan (slope) \\ h : offset tinggi pohon \\ $\mathrm{m}_{\mathrm{G}} \quad$ : peta tutupan pohon (tree cover) setelah smoothing dengan kernel Gaussian \\ $\varepsilon \quad$ : random noise}

Parameter a0... a3 dan $\mathrm{h}$ disesuaikan ke nilai $\mathrm{Z}_{\mathrm{MPD}}$ dan $\mathrm{m}_{\mathrm{G}}$ dari jendela lingkaran dengan radius 5 piksel di sekitar tiap target piksel menggunakan perataan kuadrat terkecil. Estimasi tinggi pohon $\hat{\mathrm{h}}$ ditahan jika model cukup cocok (didefinisikan dengan $\mathrm{X}^{2}<200$ dan estimasi varian $\hat{\mathrm{h}}$ kurang dari $3 \mathrm{~m}^{2}$. Koreksi ini bertujuan untuk mengubah MPD menjadi MTD. MTD ini harus memenuhi toleransi pemetaan yang ditetapkan yaitu sebesar $1,96 \sigma$ atau setara dengan $95 \%$ (Yastikh, 2006; ASPRS, 2014).

\section{Klasifikasi}

Selain data ALOS PALSAR, X SAR, dan Icesat/GLAS juga digunakan big data dari Google Earth Engine. Data ini digunakan untuk klasifikasi vegetasi. Klasifikasi vegetasi bertujuan untuk mengklasifikasi kelas vegetasi dan nonvegetasi pada wilayah kajian. Metode yang digunakan untuk klasifikasi adalah metode decision tree. Metode klasifikasi ini bisa dilakukan apabila telah tersedia tree algorithm. Tree algoritm pada penelitian ini bersifat tetap dan menggunakan beberapa sampel yang mewakili jenis objek di lokasi tersebut. Klasifikasi dengan tree algoritm memberikan akurasi dan tingkat presisi yang paling tinggi dan dapat dilakukan dalam waktu yang singkat (Julzarika \& Carolita, 2015).

\section{Tinggi Vegetasi}

Pendugaan tinggi vegetasi diperoleh dari pemotongan (cropping) MTD dan MPD dengan citra berdasarkan hasil klasifikasi. Langkah selanjutnya adalah pengurangan MPD dengan
MTD sehingga menghasilkan tinggi vegetasi (nMPD).

Tinggi vegetasi perlu dilakukan uji ketelitian terhadap pengukuran lapangan. Uji ketelitian ini berupa uji beda tinggi. Uji beda tinggi bertujuan untuk mengetahui apakah model tinggi tersebut terdapat blunder (kesalahan besar secara total) dan kesalahan acak (Julzarika \& Dewi, 2018). Kesalahan acak adalah kesalahan yang terjadi pada setiap titik ukuran. Pada penelitian ini dilakukan pengecekan 10 titik tinggi yang diambil secara acak dan kemudian dibuat poligon tertutup pada Gambar 3.

\section{Uji Akurasi}

Uji akurasi dilakukan dengan mengacu pada ASPRS Accuracy Data for Digital Geospatial Data 2014, yang ditetapkan oleh National Standard for Spatial Data Accuracy (NSSDA) (ASPRS, 2014). Uji yang dilakukan adalah Root Mean Square Error vertical (RMSE(z)) dan perhitungan akurasi vertikal pada tingkat kepercayaan 95\% (1,96 $\sigma)$. Perhitungan uji dengan membandingkan hasil tinggi vegetasi pengukuran lapangan dengan hasil MPD yang dilakukan pada tahun 2017.

$$
\operatorname{RMSE}_{(\mathrm{Z})}=\sqrt{\left(\frac{\sum\left(Z_{\text {Data }(i)}-Z_{\text {Check }(i)}\right)^{2}}{n}\right)}
$$

$$
\operatorname{Accuracy}(\mathrm{z})=1,9600 * \operatorname{RMSE}(\mathrm{z})
$$

keterangan:

$$
\begin{array}{lll}
\mathrm{Z} & : \text { nilai tinggi } \\
\mathrm{n} & : \text { jumlah titik pengukuran } \\
\mathrm{Z}_{\text {Data }} & : \text { tinggi orthometris pada MTD } \\
\mathrm{Z}_{\text {Check }} & : \text { tinggi orthometris lapangan }
\end{array}
$$

Nilai 1,9600 sama dengan tingkat kepercayaan $95 \%$.

Uji beda tinggi MTD dan MPD dilakukan dengan membuat poligon tertutup (Gambar 3). Beda tinggi diperoleh dari hasil selisih antartitik uji. Nilai tinggi titik 01 dikurangi nilai tinggi titik 02 , nilai tinggi titik 02 dikurangi nilai tinggi titik 03, dan seterusnya. Nilai beda tinggi pada akhir poligon tertutup tersebut diperoleh dari hasil pengurangan antara nilai tinggi titik 10 dengan nilai tinggi titik 01 . Nilai beda tinggi diperoleh dari jumlah beda tinggi dari setiap selisih titik uji. 


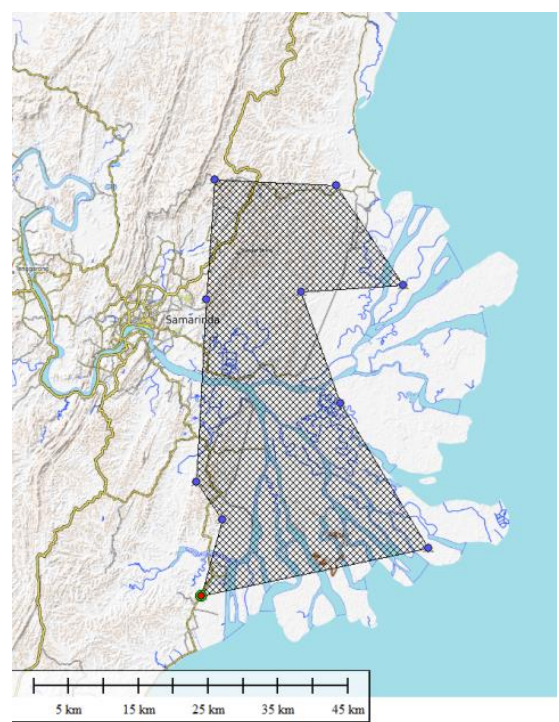

Gambar 3. Poligon titik uji.

Figure 3. Test points polygon.

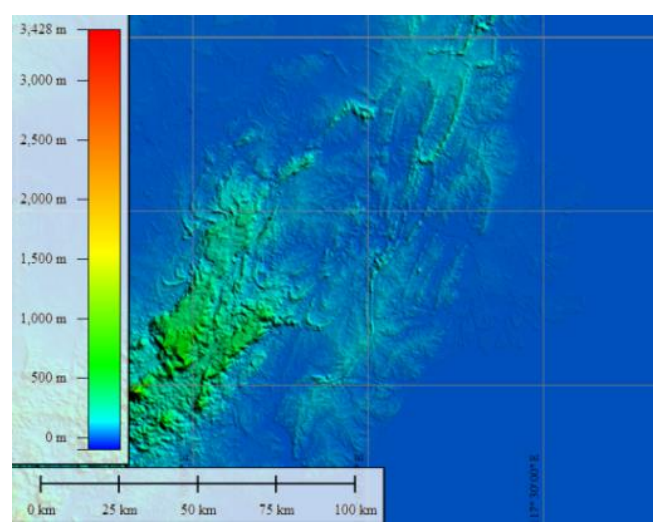

Gambar 4. MED ALOS PALSAR.

Figure 4. MED ALOS PALSAR.

\section{Hasil}

\section{MED}

Digital Elevation Model (DEM) atau Model Elevasi Digital (MED) dibuat dari MPD yang belum terkoreksi kesalahan tinggi. MED merupakan hasil pembuatan interferometri dengan menggunakan minimal dua data ALOS PALSAR. MED ini masih memiliki kesalahan tinggi berupa pits (lembah) dan spires (puncak).

Nilai MED merupakan tinggi dari tajuk vegetasi terhadap muka laut rerata. Berdasarkan hasil pengolahan MED, dapat diketahui kondisi topografi di Delta Mahakam. Gambar 4 menyajikan profil topografi di Delta Mahakam, yang bervariasi antara $0-1000 \mathrm{~m}$. Ketinggian di daerah hulu Delta Mahakam dapat mencapai hingga $1000 \mathrm{~m}$, sedangkan di daerah hilirnya berkisar antara $0-100 \mathrm{~m}$. Topografi dengan kisaran 0 - $10 \mathrm{~m}$ diwakili dengan warna biru, dan topografi dengan kisaran $300-1000 \mathrm{~m}$ diwakili dengan warna hijau.

\section{Koreksi Kesalahan Tinggi}

MED hasil interferometri perlu dilakukan koreksi kesalahan tinggi. Parameter yang digunakan pada koreksi ini adalah radius $100 \mathrm{~m}$ dan kesalahan tinggi $3 \mathrm{~m}$. Koreksi ini bertujuan untuk mencari kesalahan tinggi yang terjadi pada radius $100 \mathrm{~m}$ dan terjadi selisih tinggi lebih dari $3 \mathrm{~m}$ antara piksel yang terdapat pada radius tersebut. Kotak warna hitam menunjukkan spires yang lebih dari $3 \mathrm{~m}$ (ke arah sumbu $\mathrm{z}$ positif), sedangkan kotak warna merah adalah lokasi dengan pits yang lebih dari $3 \mathrm{~m}$ (e arah sumbu $\mathrm{z}$ negatif). Hasil yang diperoleh adalah spires pada DEM sebanyak 305 piksel dan pits sebanyak 32 piksel (Gambar 5). 


\section{MPD dan MTD}

MPD ALOS PALSAR dibuat dengan metode interferometri (Gambar 6). Hasil MPD diintegrasikan dengan data X SAR dan satelit Icesat/GLAS. Penggabungan multi MPD menggunakan metode integrasi MED (Julzarika, 2015) dan dilanjutkan dengan koreksi kesalahan tinggi dan koreksi terrain. Hasil dari koreksi tersebut menghasilkan MTD yang memiliki akurasi vertikal MTD dengan toleransi $1,96 \sigma$ (Gambar 7). Toleransi tersebut telah sesuai dengan standar National Standard for Spatial Data Accuracy (NSSDA) 2014 (ASPRS, 2014).
Gambar 5 adalah hasil dari MED yang telah dikoreksi kesalahan tinggi dan dipotong pada wilayah Delta Mahakam. Terlihat tinggi permukaan vegetasi yang berada pada elevasi 0 $100 \mathrm{~m}$. MTD menunjukkan elevasi topografi dari Delta Mahakam. Topografi bervariasi antara 0 $64 \mathrm{~m}$ dari permukaan laut rerata.

\section{Klasifikasi}

Hasil klasifikasi data menunjukkan objek vegetasi dan nonvegetasi. Objek vegetasi di Delta Mahakam terlihat di sekitar muara sedangkan yang ke arah laut semakin jarang (Gambar 8).

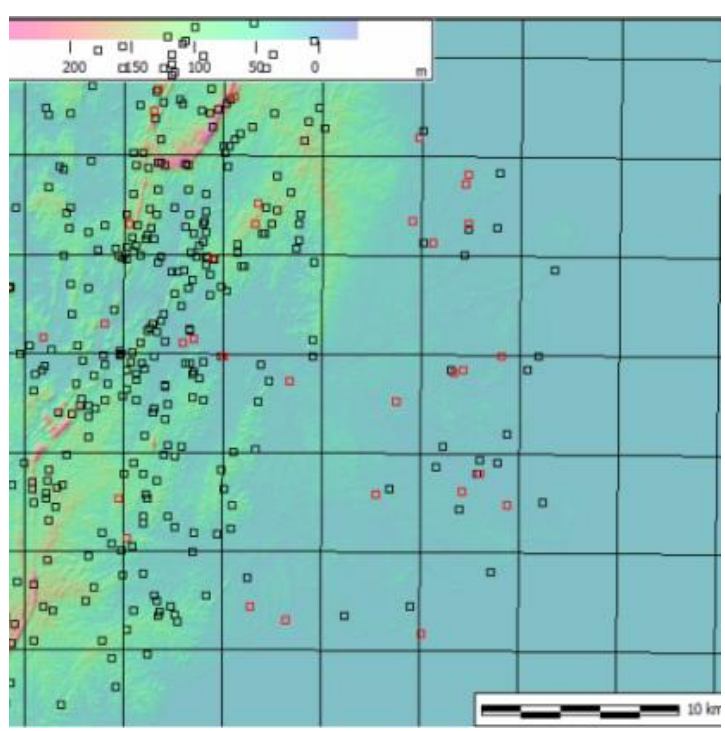

Gambar 5. Hasil koreksi kesalahan tinggi (warna hitam: spires dan warna merah: pits).

Figure 5. Height error correction results (black: spires and red: pits).

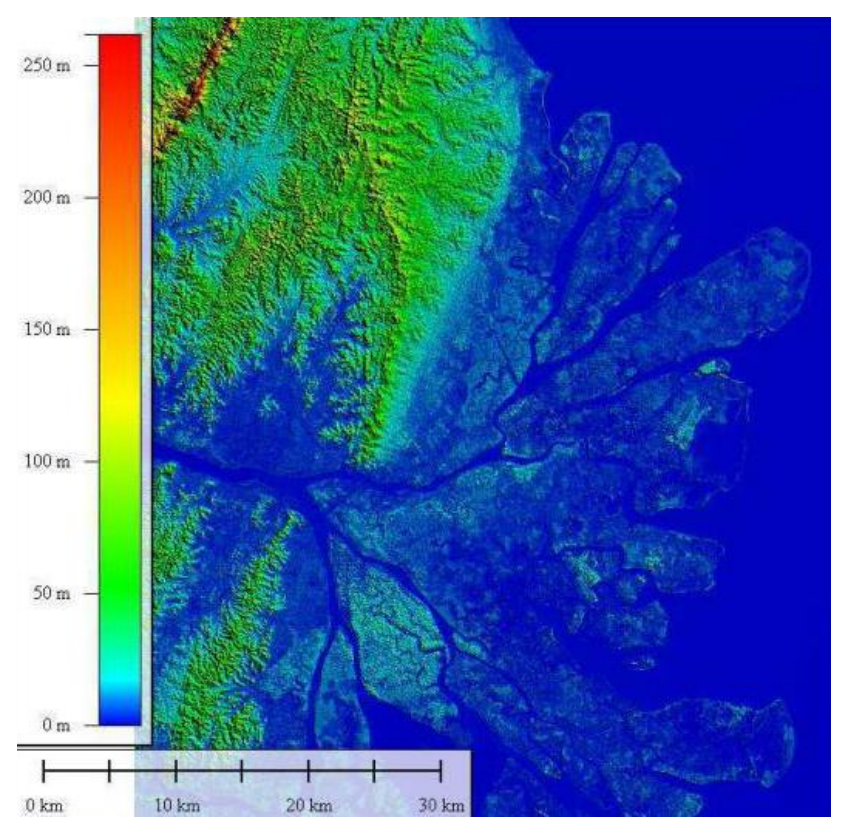

Gambar 6. Model Permukaan Digital ALOS PALSAR.

Figure 6. Digital Surface Model ALOS PALSAR. 
Anggraini \& Julzarika

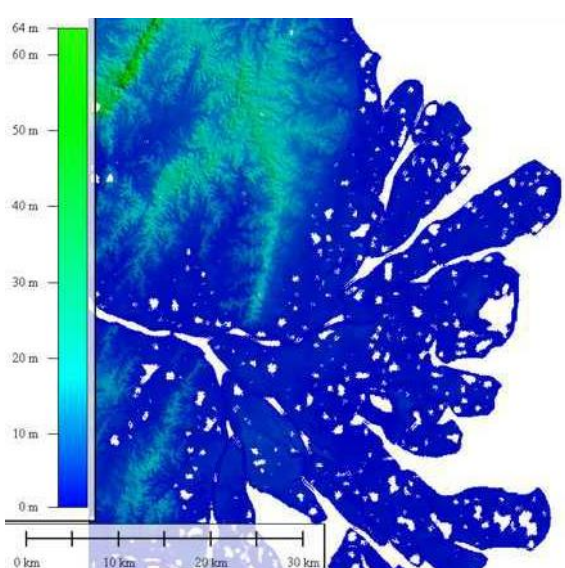

Gambar 7. Model Terrain Digital ALOS PALSAR.

Figure 7. Digital Terrain Model ALOS PALSAR.

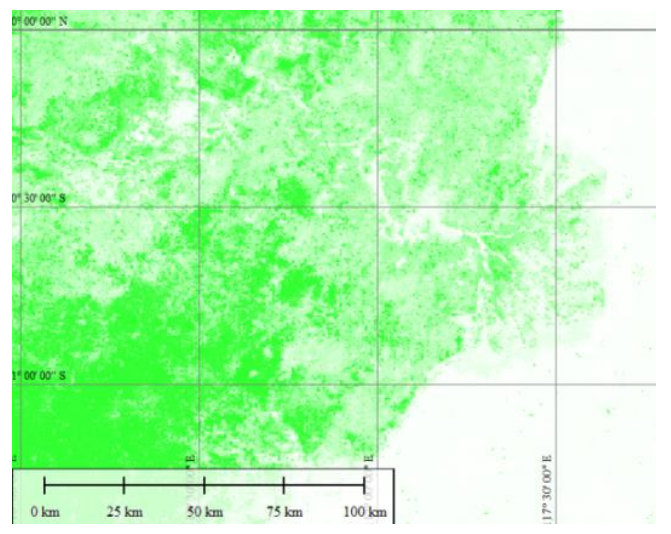

Gambar 8. Hasil klasifikasi vegetasi (hijau) dan nonvegetasi (putih).

Figure 8. Vegetation (green) and nonvegetation (white) classification result.

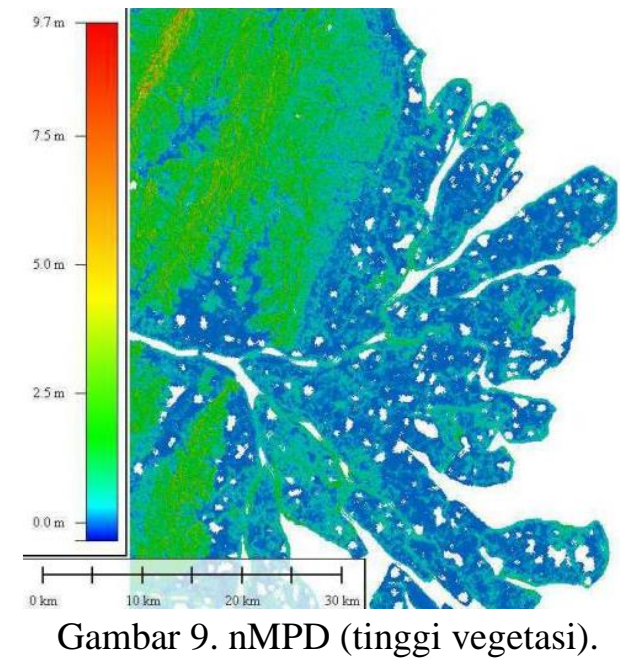

Figure 9. nMPD (vegetation height). 
Tabel 1. Uji akurasi vertikal MTD.

Table 1. Vertical accuracy test of MTD.

\begin{tabular}{ccccc}
\hline $\begin{array}{c}\text { Test } \\
\text { Point }\end{array}$ & $\begin{array}{c}\text { X-Axis } \\
\text { Coordinates } \\
(\mathbf{m})\end{array}$ & $\begin{array}{c}\text { Y-Axis } \\
\text { Coordinates } \\
(\mathbf{m})\end{array}$ & $\begin{array}{c}\text { Digital } \\
\text { Terrain } \\
\text { Model } \\
(\mathbf{m})\end{array}$ & $\begin{array}{c}\text { Height } \\
\text { Difference (m) }\end{array}$ \\
\hline 01 & 543813.7 & 9964600 & 9.041 & \\
02 & 553336.4 & 9950316 & 0.915 & - \\
03 & 544373.8 & 9933371 & 2.544 & -1.629 \\
04 & 556977.5 & 9912645 & 1.527 & 1.017 \\
05 & 524488.0 & 9905923 & 2.504 & -0.977 \\
06 & 523787.8 & 9922167 & 12.288 & -9.784 \\
07 & 526448.6 & 9965440 & 12.490 & -0.202 \\
08 & 538772.2 & 9949335 & 20.226 & -7.736 \\
09 & 525188.2 & 9948215 & 17.232 & 2.994 \\
10 & 527506.0 & 9916730 & 8.437 & 8.795 \\
01 & 543813.7 & 9964600 & 9.041 & -0.604 \\
& High Difference Test & & $\mathbf{0 . 0 0 0}$ \\
\hline
\end{tabular}

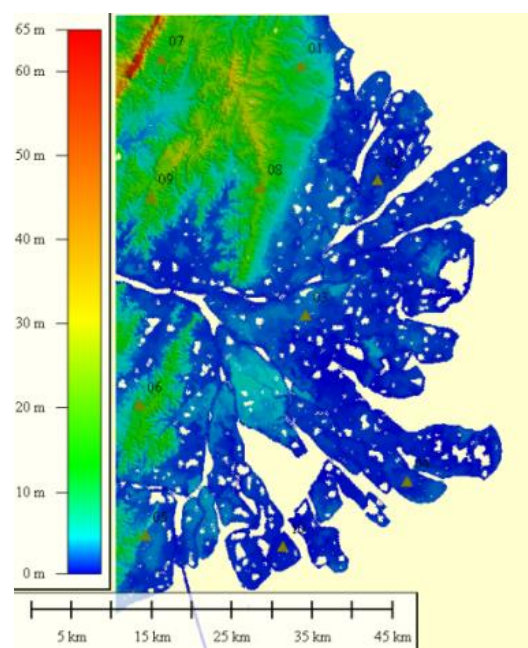

Gambar 10. Lokasi titik uji vertikal MTD.

Figure 10. Vertical accuracy test location of MTD.

Tabel 2. Uji akurasi vertikal MPD.

Table 2. Vertical accuracy test of MPD.

\begin{tabular}{ccccc}
\hline $\begin{array}{c}\text { Test } \\
\text { Point }\end{array}$ & $\begin{array}{c}\text { X-Axis } \\
\text { Coordinates } \\
(\mathbf{m})\end{array}$ & $\begin{array}{c}\text { Y-Axis } \\
\text { Coordinates } \\
(\mathbf{m})\end{array}$ & $\begin{array}{c}\text { Digital } \\
\text { Surface } \\
\text { Model }(\mathbf{m})\end{array}$ & $\begin{array}{c}\text { Height } \\
\text { Difference } \\
(\mathbf{m})\end{array}$ \\
\hline 01 & 543813.7 & 9964600 & 9.946 & - \\
02 & 553336.4 & 9950316 & 0.916 & 9.030 \\
03 & 544373.8 & 9933371 & 2.701 & -1.785 \\
04 & 556977.5 & 9912645 & 1.535 & 1.166 \\
05 & 524488.0 & 9905923 & 2.700 & -1.165 \\
06 & 523787.8 & 9922167 & 13.341 & -10.641 \\
07 & 526448.6 & 9965440 & 13.786 & -0.445 \\
08 & 538772.2 & 9949335 & 21.199 & -7.413 \\
09 & 525188.2 & 9948215 & 19.634 & 1.565 \\
10 & 527506.0 & 9916730 & 9.567 & 10.067 \\
01 & 543813.7 & 9964600 & 9.946 & -0.379 \\
\multicolumn{5}{r}{ High Difference Test } \\
\hline
\end{tabular}




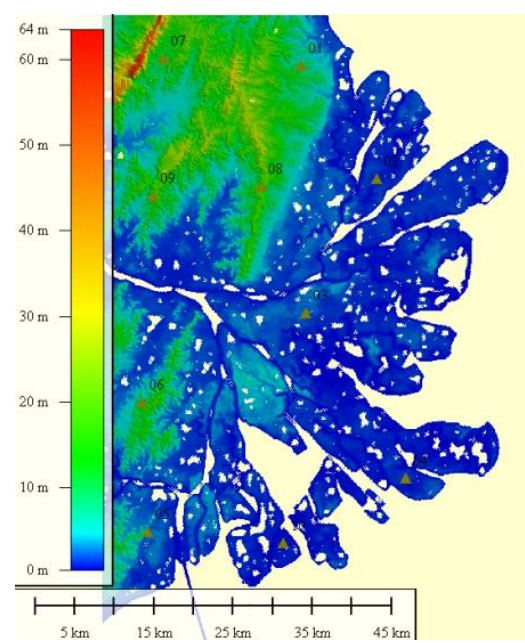

Gambar 11. Lokasi titik uji vertikal MPD.

Figure 11. Vertical accuracy test location of MPD.

\section{Tinggi vegetasi}

Tinggi vegetasi diperoleh dari hasil overlay antara MTD dengan hasil klasifikasi. Pada data model tinggi, tinggi permukaan (surface) umumnya merupakan gabungan dari vegetasi dan bangunan. Objek vegetasi mendominasi wilayah Delta Mahakam untuk pemetaan dengan skala 1:10.000, objek bangunan diabaikan. Penelitian ini hanya fokus pada perhitungan dan pemodelan tinggi vegetasi di Delta Mahakam. Berdasarkan hasil pengolahan nilai nMPD, maka diperoleh tinggi relatif vegetasi di Delta Mahakam yang berkisar pada 2,5 - 9,7 m (Gambar 9).

\section{Uji Akurasi}

Hasil yang diperoleh berupa jumlah beda tinggi antar setiap 10 titik (Gambar 10 dan Gambar 11). Jumlah total beda tinggi tersebut mendekati nol $(\sim 0)$, seperti yang disajikan pada Tabel 1 dan Tabel 2. Hal ini menandakan bahwa MPD dan MTD yang digunakan untuk perhitungan tinggi vegetasi telah bebas blunder dan kesalahan acak.

\section{Pembahasan}

Setelah diperoleh informasi tinggi vegetasi maka diperlukan adanya uji ketelitian terhadap hasil yang diperoleh tersebut. Toleransi pada NSSDA 2014 (ASPRS 2014) terkait akurasi vertikal untuk skala 1:10.000 harus memenuhi angka 1,96 $\sigma(95 \%)$ sebesar minimal $80 \mathrm{~cm}$. Pada hasil pengolahan MPD dengan persamaan 2 dan 3 , diperoleh nilai akurasi vertikal sebesar $60,4 \mathrm{~cm}$ sehingga dapat digunakan pada pemetaan 1:10.000. Berdasarkan hasil perhitungan dengan menggunakan persamaan 2 dan 3 maka diperoleh nilai uji akurasi vertikal MTD sebesar $37 \mathrm{~cm}$ sehingga dapat juga digunakan untuk pemetaan skala 1:10.000. Hal ini menunjukkan bahwa MPD dan MTD telah memenuhi syarat untuk pemetaan skala 1:10.000, sehingga tinggi vegetasi yang dihasilkan dapat digunakan untuk aplikasi pemetaan skala 1:10.000.

Penelitian dengan metode ini lebih efisien karena menggunakan data ALOS PALSAR dengan citra XSAR, Shuttle Radar Topography Mission (SRTM), dan tinggi orthometris dari satelit Icesat/GLAS yang bebas untuk diakses. Selain itu, metode ini juga efektif didalam waktu pengerjaannya karena tidak diperlukan perekaman di lokasi kajian. Beberapa penelitian sebelumnya, menggunakan data LIDAR yang memerlukan biaya mahal dan memerlukan waktu lama dalam pengolahannya (Garcia et al., 2018).

Akurasi vertikal LIDAR lebih tinggi dibandingkan dengan akurasi vertikal riset ini, namun hasil riset ini masih dapat digunakan karena telah memenuhi toleransi NSSDA 2014. Pada penelitian ini, kombinasi dengan data dari Icesat/GLAS yang menyebabkan akurasi vertikal lebih tinggi.

\section{Kesimpulan}

Tinggi vegetasi diukur dengan mengurangkan MPD dengan MTD pada kelas penutup lahan vegetasi. MPD dibuat dengan citra ALOS PALSAR secara interferometri dan integrasi MED dengan data $X$ SAR dan Icesat/GLAS. Tinggi vegetasi ini bersifat relatif yang menggambarkan kondisi dominan pada setiap piksel MTD. MTD diperoleh dari hasil 
koreksi terrain terhadap MPD. Tinggi vegetasi ini bisa digunakan juga untuk aplikasi volume permukaan (surface volume). Pada MTD, diperoleh nilai akurasi vertikal sebesar $60,4 \mathrm{~cm}$ sehingga MTD ini layak digunakan pada pemetaan 1:10.000. Adapun pada MPD diperoleh nilai uji akurasi vertikal sebesar $37 \mathrm{~cm}$ sehingga dapat juga digunakan untuk pemetaan skala 1:10.000. MPD, MTD, dan tinggi vegetasi ini dapat digunakan pada pemetaan skala 1:10.000.

\section{Ucapan Terima Kasih}

Terima kasih diucapkan kepada Universitas Gadjah Mada, Pusat Pemanfaatan Penginderaan Jauh-LAPAN dan Alaska University atas dukungannya selama ini.

\section{Daftar Pustaka}

Arifantia, V. B., Kauffman, J. B., Hadriyanto, D., Murdiyarso, D., \& Diana, R. (2019). Carbon dynamics and land use carbon footprints in mangrove-converted aquaculture: The case of the Mahakam Delta, Indonesia. Forest Ecology and Management, 432, 17-29. https://doi.org/10.1016/j.foreco.2018.08.047 ASPRS. (2014). ASPRS Accuracy Standard for Digital Geospatial Data. ASPRS. Amerika Serikat.

Freeden, W., Nashed, M. Z., \& Sonar, T. (2010). Handbook of Geomathemathics. Springer.Kota terbit.

Garcia, M., Saatchi, S., Ustin, \& Balzter, H. (2018). Modelling Forest Canopy Height By Integrating Airborne LIDAR Samples With Satellite Radar And Multispectral Imagery. Int J Appl Earth Obs Geoinformation, 66, 159-173.

https://doi.org/10.1016/j.jag.2017.11.017

Gastaldo, R. A. (2010). Peat or no peat: Why do the Rajang and Mahakam Deltas differ? International Journal of Coal Geology, 83, 162-172. DOI: 10.1016/j.coal.2010.01.005

Gillani, C, \& Wolf. (2006). Adjustment Computations: Spatial Data Analysis. John Wiley and Sons, Inc., Hoboken, New Jersey. Amerika Serikat.

Goel, K. (2013). Advanced Stacking Techniques and Applications in High Resolution SAR Interferometry, München: Universität München.

Hoja, D. \& d'Angel, P. (2010). Analysis of
DEM Combination Methods Using High Resolution Optical Stereo Imagery And Interferometric SAR Data, International Archives of the Photogrammetry, Remote Sensing and Spatial Information Science, Volume XXXVIII, Part 1, Calgary, Kanada.

Hoja, D., Reinartz, P., \& Schroeder, M. (2006). Comparison Of DEM Generation And Combination Methods Using High Resolution Optical Stereo Imagery And Interferometric SAR Data. International Archives of the Photogrammetry. Remote Sensing and Spatial Information Science. Volume XXXVI. Part 1. Paris. Perancis.

Iskandar. (2010). Kerusakan Hutan Mangrove Delta Mahakam Sangat Parah. https://kaltim.antaranews.com/berita/2821/k erusakan-hutan-mangrove-delta-mahakamsangat-parah. Diakses 7 juni 2018.

JAXA. (2018). PALSAR Phased Array type Lband Synthetic Aperture Radar, URL: https://www.eorc.jaxa.jp/ALOS/en/about/pa lsar.htm. Diakses pada Desember 2018.

Julzarika, A. (2011). Teknik Koreksi Bull Eye's. GeoSARNas. Bogor.

Julzarika, A. (2013). Geological Structure Detection Digitally Using Synthetic Aperture Radar (SAR) Data. Asia Conference of Remote Sensing. Bali. Indonesia.

Julzarika, A. (2015). Height model integration using ALOS PALSAR, X SAR, SRTM C, and Icesat/GLAS. International Journal of Remote Sensing and Earth Science, 12 (2), 107-116.

Julzarika, A. \& Carolita, I., (2015). Klasifikasi Penutup Lahan Berbasis Objek Pada Citra SPOT dengan Menggunakan Metode Tree Algorithm. Majalah Ilmiah Globe, 17 (2), 97-104.

Julzarika, A., \& Dewi, E. K. (2018). Uji Akurasi Vertikal DTM ALOS PALSAR Terhadap Pengukuran Kombinasi DGNSS-Altimeter. Jurnal Penginderaan Jauh dan Pengolahan Citra Digital, 15 (1), 11-24. http://dx.doi.org/10.30536/j.pjpdcd.2018.v1 5. 22804

Kumay, D. U. (2015). Remote Sensing Platforms and Sensor. NBKRIST Vidyanagar. India.

Li, Z., Zhu, Q. \&. Gold, C. M. (2005). Digital Terrain Modeling Principles and Methodology. CRC Press. Florida. USA.

Lembaga Ilmu Pengetahuan Indonesia. (2018). Limnologi LIPI. http://www.limnologi.lipi.go.id/aboutus.php 
?id=2. Diakses Juli 2018.

Noggle, G.R, \& Frits, G.J. (1983). Introduction Plant Physiology. Second Edition. New Jersey: Prentice Hall, Inc, Englewood Clifts.

Petrie, G. \& Kennie, T. (1987). An introduction to terrain modeling: applications and terminology. Universitas Glasgow, Skotlandia.

Sarmap. (2017). Synthetic Aperture Radar and SARScape.

URL:

http://www.sarmap.ch/pdf/SAR-

Guidebook.pdf. diakses Maret 2018.

Sayekti, R.B. (2002). Pengelolaan Terpadu DAS dan Delta Mahakam. Tirta Pela, 12(1), 1-4.

Suhardimana, A., Tsuyuki, S., \& Setiawan, Y. (2016). Estimating mean tree crown diameter of mangrove stands using aerial photo. Procedia Environmental Sciences, 33, $416 \quad-\quad 427$. https://doi.org/10.1016/j.proenv.2016.03.09 2

Trisakti, B., \& Julzarika, A. (2011). DEM
Generation from Stereo ALOS Prism and Its Quality Improvement. International Journal of Remote Sensing and Earth Sciences, $8, \quad 41-48 . \quad$ doi : 10.30536/j.ijreses.2011.v8.a1740

Vanicek, P. \& Krakiwsky, E. (1986). Geodesy, the concepts. North-Holland, Amsterdam, NY, Oxford, Tokyo.

Yastikh. (2006). Accuracy and Morphological Analyses of GTOPO3O and SRTM X-C band DEMS in the Test Area Istambul, ISPRS Workshop, Ankara, Turki.

Yayasan Mangrove Lestari. (2012). About Delta Mahakam.

http://ymldeltamahakam.blogspot.com/2012 /11/about-delta-mahakam.html. diakses 7 juni 2018.

Zimmerman, D. L. \& Cressie, N. (1992). Mean squared prediction error in the spatial linear model with estimated covariance parameters. Annuals of the Institute of Statistical Mathematics, 44, 27-43. 